Atmos. Chem. Phys., 14, 4573-4585, 2014

www.atmos-chem-phys.net/14/4573/2014/

doi:10.5194/acp-14-4573-2014

(c) Author(s) 2014. CC Attribution 3.0 License.

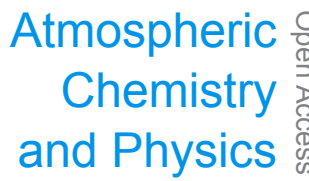

\title{
Impact of biomass burning on haze pollution in the Yangtze River delta, China: a case study in summer 2011
}

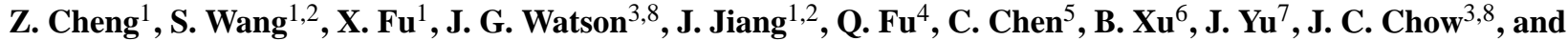 \\ J. Hao ${ }^{1,2}$ \\ ${ }^{1}$ School of Environment, and State Key Joint Laboratory of Environment Simulation and Pollution Control, Tsinghua \\ University, Beijing 100084, China \\ ${ }^{2}$ State Environmental Protection Key Laboratory of Sources and Control of Air Pollution Complex, Beijing 100084, China \\ ${ }^{3}$ Division of Atmospheric Sciences, Desert Research Institute, 2215 Raggio Parkway, Reno, NV 89512, USA \\ ${ }^{4}$ Shanghai Environmental Monitoring Center, Shanghai 200030, China \\ ${ }^{5}$ Shanghai Academy of Environmental Sciences, Shanghai 200233, China \\ ${ }^{6}$ Zhejiang Environmental Monitoring Center, Hangzhou 310015, China \\ ${ }^{7}$ Jiangsu Environmental Monitoring Center, Nanjing 210036, China \\ ${ }^{8}$ SKLLQG, Institute of Earth Environment, Chinese Academy of Sciences, Xi' an 710075, China
}

Correspondence to: S. Wang (shxwang@tsinghua.edu.cn)

Received: 18 August 2013 - Published in Atmos. Chem. Phys. Discuss.: 25 November 2013

Revised: 17 March 2014 - Accepted: 19 March 2014 - Published: 12 May 2014

\begin{abstract}
Open biomass burning is an important source of air pollution in China and globally. Joint observations of air pollution were conducted in five cities (Shanghai, Hangzhou, Ningbo, Suzhou and Nanjing) of the Yangtze River delta, and a heavy haze episode with visibility $2.9-9.8 \mathrm{~km}$ was observed from 28 May to 6 June 2011. The contribution of biomass burning was quantified using both ambient monitoring data and the WRF/CMAQ (Weather Research and Forecasting (WRF) and Community Multiscale Air Quality (CMAQ)) model simulation. It was found that the average and maximum daily $\mathrm{PM}_{2.5}$ concentrations during the episode

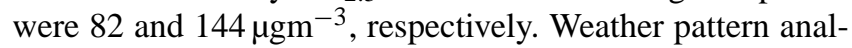
ysis indicated that stagnation enhanced the accumulation of air pollutants, while the following precipitation event scavenged the pollution. Mixing depth during the stagnant period was 240-399 m. Estimation based on observation data and CMAQ model simulation indicated that biomass open burning contributed $37 \%$ of $\mathrm{PM}_{2.5}, 70 \%$ of organic carbon and $61 \%$ of elemental carbon. Satellite-detected fire spots, backtrajectory analysis and air quality model simulation were integrated to identify the locations where the biomass was burned and the pollutants transport. The results suggested that the impact of biomass open burning is regional, due to the substantial inter-province transport of air pollutants.
\end{abstract}

$\mathrm{PM}_{2.5}$ exposure level could be reduced $47 \%$ for the YRD region if complete biomass burning is forbidden and significant health benefit is expected. These findings could improve the understanding of heavy haze pollution, and suggest the need to ban open biomass burning during post-harvest seasons.

\section{Introduction}

Emissions from biomass open burning have significant regional and global impacts on human health, visibility, and climate (Crutzen and Andreae, 1990; Penner et al., 1992; Watson, 2002). In eastern China, large amounts of crop residues are burned in the field during the post-harvest seasons (i.e., May-June and October-November) (Streets et al., 2003; Yan et al., 2006). The open burning of biomass could cause severe regional air pollution and haze issue in the Pearl River delta (PRD), the Yangtze River delta (YRD) and Beijing-Tianjin-Hebei areas of China (Wang et al., 2007; Li et al., 2010; Z. Zhang et al., 2010; Zhu et al., 2010; Yin et al., 2011; K. Huang et al., 2012; Cheng et al., 2013).

The YRD, including seven cities of northern Zhejiang Province, the Shanghai municipality and eight cities of southern Jiangsu Province (as shown in Fig. 1b), is 
one of the city clusters in eastern China with the area of $110915 \mathrm{~km}^{2}$ and the population of 108.6 million (http://china-trade-research.hktdc.com/business-news/ article/Fast-Facts/Yangtze-River-Delta-Profile/ff/en/1/ 1X000000/1X06BW0C.htm). Heavy industries including petro-chemistry, iron and steel production, and automobile manufacturing drive the YRD economy. In the meanwhile, the YRD is also a large producer of agricultural products, including wheat, rice, corn and cole flowers, resulting in large amounts of crop residue being openly burned (Zhu et al., 2012). Previous studies about biomass burning in the YRD mainly focus on either Nanjing (Zhang et al., 2011; Gao et al., 2012; Su et al., 2012; Zhu et al., 2012) or Shanghai (K. Huang et al., 2012; Zhang et al.,2011). Since biomass burning is distributed over a large area of the YRD rural region, its emissions can be transported over long distances under synoptic weather influence (Cheng et al., 2011), implying the necessity for regional joint observation and analysis to investigate pollutant transport and accumulation.

Biomass burning usually occurs in the forms of prescribed burning or residential wood heating in developed countries. For the prescribed burning, the concentration contribution is estimated to vary at $0.3-5.1{\mu \mathrm{gm}^{-3}}^{-3.8-43 \%}$ of the monthly ambient $\mathrm{PM}_{2.5}$ (particles with aerodynamic diameters no more than $2.5 \mu \mathrm{m}$ ) load in Australia and the United States (Reisen et al., 2013; Tian et al., 2009). The contribution of residential wood heaters is at the range of 3.2-9.8 $\mu \mathrm{gm}^{-3} 27-$ $77 \%$ of the seasonal $\mathrm{PM}_{2.5}$ load in winter of southeastern United States and Australia (Reisen et al., 2013; X. Zhang et al., 2010). In the winter in Portugal, the contributions of residential wood heaters to seasonal organic carbon (OC) and elemental carbon (EC) reaches 12.3 and $1.8 \mu \mathrm{gm}^{-3}$, accounting for 64 and $11 \%$, respectively (Gelencsér, 2007). The biomass burning contribution to seasonal ambient $\mathrm{PM}_{2.5}$ mass is much higher in China, that is, $12-27 \mu \mathrm{gm}^{-3}$ (15$24 \%$ ) in Beijing (Cheng et al., 2013; Song et al., 2007; Wang et al., 2009), 5.4-25.4 $\mathrm{\mu gm}^{-3}$ (4-19\%) in Guangzhou (Wang et al., 2007), and $8-64 \mu \mathrm{gm}^{-3}$ (below $70 \%$ ) in Southeast Asia and south China (Fu et al., 2012). For the YRD region, contribution of biomass burning to the ambient $\mathrm{PM}_{2.5}$ concentrations are seldom quantified and reported, especially for a heavy haze episode. Such information is vital for development of further pollution control strategies.

In this study, joint observations of air pollution were conducted in five cities (Shanghai, Hangzhou, Ningbo, Suzhou and Nanjing) of the YRD. A heavy haze episode with pretty low visibility was observed from 28 May to 6 June 2011. The impacts of meteorological conditions were analyzed. The contribution of biomass burning to $\mathrm{PM}_{2.5}$ mass and carbon concentrations were quantified using the method of source markers and air quality model simulations.

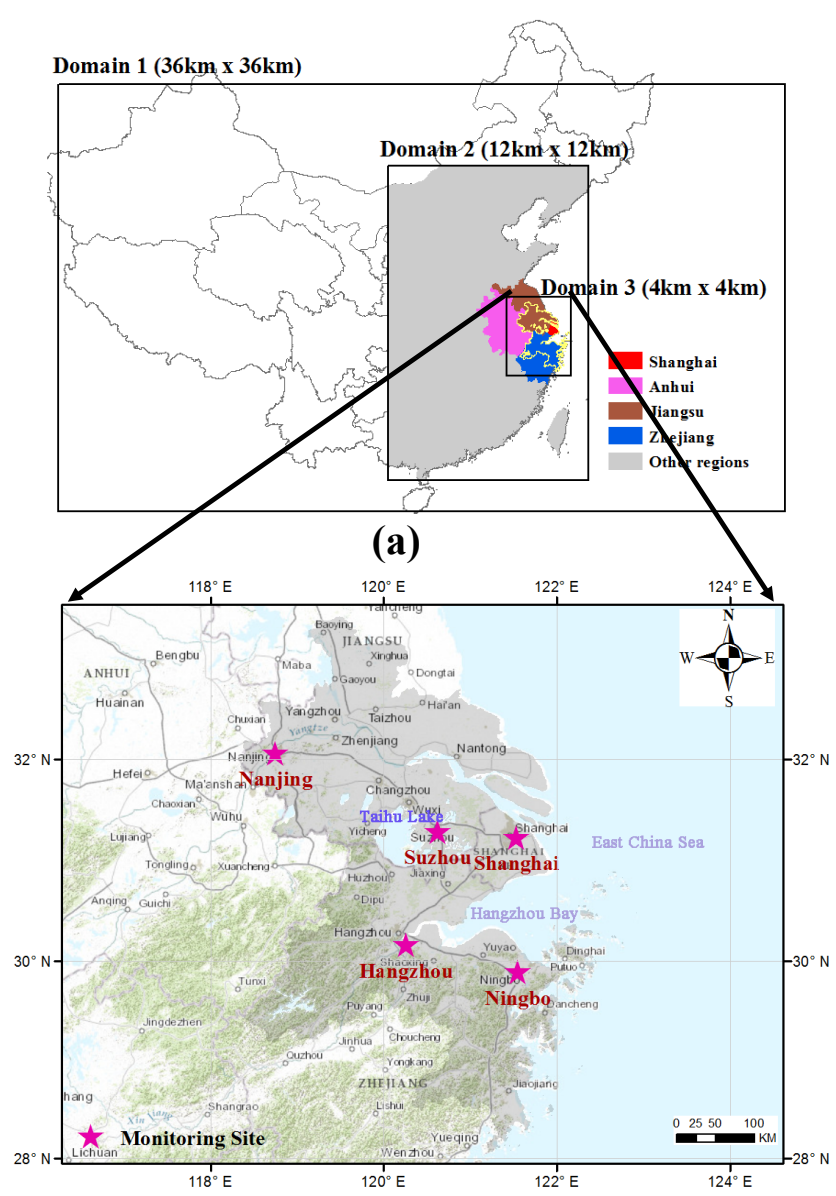

(b)

Fig. 1. Model domain and location of measurement sites. (a) Three nested domain grids for WRF/CMAQ modeling. (b) Location of field monitoring sites. The yellow border in (a) and gray area in (b) constitute the YRD region. The five regions indicated by different colors in panel (a) were used for WRF/CMAQ sensitivity analyses, with biomass burning emissions set to zero in each region to determine their effects on concentrations of $\mathrm{PM}_{2.5}$ and carbon species.

\section{Materials and methods}

\subsection{Field observations}

Five sampling sites were located in Ningbo and Hangzhou of Zhejiang Province, and Shanghai, Suzhou and Nanjing of Jiangsu Province to represent urban residential and commercial areas (Fig. 1b). These sites were 100-300 km apart to characterize urban-to-regional scale zones of influence (Chow et al., 2002). Site details were given in Table S1 and discussed in the Supplement. Data used here included the continuous hourly $\mathrm{PM}_{2.5}$ and $\mathrm{PM}_{10}$ (particles with aerodynamic diameters no more than $10 \mu \mathrm{m}$ ) mass concentrations measured by tapered element oscillating microbalance (TEOM) at $50^{\circ} \mathrm{C}$, meteorological parameters including 
relative humidity $(\mathrm{RH})$, temperature, wind speed/direction, and visual range (forward light scattering) for all five sites. Furthermore, daily average concentrations of $\mathrm{PM}_{2.5}$ species were obtained by filter sampling and chemical analysis in the laboratory at the sites of Shanghai, Suzhou and Nanjing.

The TEOM lost some of the volatile particulate matter $(\mathrm{PM})$ at $50^{\circ} \mathrm{C}$, but comparisons with collocated filters showed that this loss was less than $10-20 \%$ of the gravimetric mass (Chow et al., 2008). The Belfort and Vaisala forward scattering devices used for visual range measurement correlated well with the human observations at nearby meteorological stations, with $R^{2}=0.73-0.87$ and regression slopes of 0.91-1.03. Daily, $22 \mathrm{~h}$ (14:00 to 12:00 LST on the following day) $\mathrm{PM}_{2.5}$ Teflon-membrane and quartz-fiber filter samples were also taken. The mass concentrations of $\mathrm{PM}_{2.5}$ and its metal elements, ions and carbonaceous matter were analyzed in the lab, and the detail information was given in Table S2 and text in the Supplement. Organic matter $(\mathrm{OM})$ was estimated by $1.55 \times \mathrm{OC}$ to account for unmeasured hydrogen $(\mathrm{H})$ and oxygen $(\mathrm{O})$ according to HR-ToFAMS (high-resolution time-of-flight aerosol mass spectrometer) and SP2 measurements in Shanghai (X.-F. Huang et al., 2012). Crustal material was calculated by the weighted summary of five major crustal elements, $\mathrm{Al}, \mathrm{Si}, \mathrm{Ca}, \mathrm{Fe}$, and $\mathrm{Ti}$ (Lowenthal and Kumar, 2003). The trace species consist of the elements measured by X-ray fluorescence (XRF) with the removal of crustal elements (Yang et al., 2011). Nonsoil potassium $\left(\mathrm{K}^{+}\right)$, which was calculated as water-soluble $\mathrm{K}^{+}$minus the part of crustal part which was $0.6^{*}[\mathrm{Fe}]$ (Hand, 2011), could be regarded as being from biomass burning (Wang et al., 2007).

\subsection{Regional meteorology and fire emissions}

Mixing depths and precipitation data were obtained from the Global Data Assimilation System (GDAS) model (Rolph, 2013), which was run at 00:00, 06:00, 12:00, and 18:00 UTC and gave the analysis file of current time as well as the forecast file for $3 \mathrm{~h}$ later. The UTC time was converted to LST time by adding $8 \mathrm{~h}$ for Beijing time in China. Mixing depths correspond to each time, while precipitation was cumulative for $3 \mathrm{~h}$ before the indicated time. Mixing depths of GDAS have been verified by comparison with the vertical lidar observation and agreed well in Shanghai (K. Huang et al., 2012). The Hybrid Single-Particle Lagrangian Integrated Trajectory (HYSPLIT ) model (Draxler and Rolph, 2013; Rolph, 2013) was run in the back-trajectory mode at $100 \mathrm{~m}$ a.g.l. (above ground level) starting at 12:00 LST of 31 May and 4 June, and every $3 \mathrm{~h}$ repeated thereafter, for the running time of previous $24 \mathrm{~h}$.

Active fire locations and brightness were obtained from the Fire Information for Resource Management System (FIRMS) derived from the Moderate Resolution Imaging Spectroradiometer (MODIS) (Davies et al., 2009). Daily $500 \mathrm{hPa}$ height and surface weather patterns analysis chart over East Asia were obtained from the Korea Meteorological Administration.

\subsection{Receptor modeling for source apportionment}

The tracer solution to the chemical mass balance (CMB) receptor model (Watson et al., 2008) was used to estimate the contributions of biomass burning to $\mathrm{PM}_{2.5}$ mass concentrations. Biomass burning markers include water-soluble $\mathrm{K}^{+}$(Cheng et al., 2013; Duan et al., 2004), levoglucosan (Sullivan et al., 2008; Wang et al., 2007) and black carbon (BC) absorption concentration differences between 330 and $88 \mathrm{~nm}$ (Y. Wang et al., 2011). In this study, non-soil watersoluble $\mathrm{K}^{+}$was used as the marker of biomass burning as it is the only marker quantified. The ratios of $\left[\mathrm{PM}_{2.5}\right] /$ [nonsoil $\mathrm{K}^{+}$], [OC]/[non-soil $\mathrm{K}^{+}$] and $[\mathrm{EC}] /$ [non-soil $\mathrm{K}^{+}$] for biomass burning source profiles were decided according to literature results. Then these ratios were multiplied by the ambient non-soil $\mathrm{K}^{+}$levels determined from each $\mathrm{PM}_{2.5}$ filter sample to determine the contribution of biomass burning. It shall be noticed that the results of this method only included the primary $\mathrm{PM}_{2.5}$ or OC contribution emitted directly by biomass burning, and did not cover the secondary $\mathrm{PM}_{2.5}$ or OC contribution oxidized from the gaseous pollutant emitted by biomass burning.

\subsection{WRF/CMAQ model}

The Weather Research and Forecasting (WRF) model (version 3.3.1) and Community Multiscale Air Quality (CMAQ) model (version 5.0), which are widely used over the world (Knipping et al., 2006; Wang et al., 2010; Fu et al., 2012), were used to simulate the pollution episode. The CMAQ modeling domains were shown in Fig. 1a, with the outer domain of $36 \mathrm{~km} \times 36 \mathrm{~km}$ for China, the medium domain of $12 \mathrm{~km} \times 12 \mathrm{~km}$ for eastern China and the inner domain of $4 \mathrm{~km} \times 4 \mathrm{~km}$ for the YRD area. Twenty-four vertical layers were included from the height of the surface to $100 \mathrm{mbar}$ (about $16 \mathrm{~km}$ ), of which thirteen layers are included under the boundary layer height of $2 \mathrm{~km}$. The first guess fields of WRF model were from the analysis data of the National Center for Environmental Prediction (NCEP), as well as the automated data processing (ADP) data used for four-dimensional data assimilation. The updated 2005 carbon bond gas-phase mechanism (CB05) (Whitten et al., 2010) and the AERO6 aerosol module with updates of primary organic aerosol (POA) aging (Simon and Bhave, 2012) and secondary organic aerosol (SOA) yield parameterization were used in CMAQ model. The detailed information about WRF and CMAQ model configuration and parameters were given in Fu et al. (2014). The anthropogenic emissions inventory was based on the local energy consumption statistics, and measured emission factors for both China (domains 1 and 2) (S. Wang et al., 2011) and the YRD region (domain 3) (Fu et al., 2013). Biomass burning emissions were temporally and 
spatially allocated according to the detected time and brightness of fire points derived from FIRMS (Davies et al., 2009). Natural biogenic VOCs emissions were generated from the MEGAN model (Guenther et al., 2006).

The contribution of biomass burning to $\mathrm{PM}_{2.5}$ and its species concentrations was estimated using sensitivity analyses (Fu et al., 2012). The base case included emissions of all sources from all of the five sub-regions and was followed by additional five runs in which biomass burning emissions for each sub-region were dropped to zero in sequence (as shown in Fig. 1a). The difference between the base case $\mathrm{PM}_{2.5} / \mathrm{OC} / \mathrm{EC}$ and each of the next five cases provides the contribution from that region to each receptor. The difference summary of all sub-regions was regarded as the total contribution of biomass burning. The receptors here only referred to the five grid cells where monitoring sites were located.

\section{Results and discussion}

\subsection{Characteristics of particulate matter pollution}

Figure 2 shows hourly $\mathrm{PM}_{10}$ and $\mathrm{PM}_{2.5}$ mass concentrations from the TEOM during the biomass burning episode. During this episode, daily average $\mathrm{PM}_{10}$ concentration of all sites is $124 \mu \mathrm{gm}^{-3}$, ranging from 88 (Shanghai) to $151 \mathrm{\mu gm}^{-3}$ (Nanjing), while the daily average $\mathrm{PM}_{2.5}$ concentration is $82 \mu \mathrm{gm}^{-3}$, ranging from 67 (Shanghai) to $98 \mu \mathrm{gm}^{-3}$ (Nanjing). During the entire year (from 1 May 2011 to 30 April 2012), the daily average concentration of the five sites is $86 \mu \mathrm{gm}^{-3}$ for $\mathrm{PM}_{10}$ and $50 \mu \mathrm{gm}^{-3}$ for $\mathrm{PM}_{2.5}$. The average $\mathrm{PM}_{10}$ and $\mathrm{PM}_{2.5}$ concentrations of the episode are 44 and $76 \%$ higher than the average of the entire year. In addition, the $\mathrm{PM}_{2.5} / \mathrm{PM}_{10}$ mass ratio was $66 \%$ during the episode, $58 \%$ higher than the annual average. The maximum daily average concentrations are $209 \mu \mathrm{gm}^{-3}$ for $\mathrm{PM}_{10}$ and $144 \mu \mathrm{gm}^{-3}$ for $\mathrm{PM}_{2.5}$, indicating that $\mathrm{PM}_{2.5}$ is the major cause of this haze event. The peak daily concentrations occur on 31 May for Hangzhou ( $\mathrm{PM}_{10}$ : $300 \mu \mathrm{gm}^{-3} ; \mathrm{PM}_{2.5}: 220 \mu \mathrm{gm}^{-3}$ ), followed by 1 June for Ningbo $\left(\mathrm{PM}_{10}: 238 \mu \mathrm{gm}^{-3} ; \mathrm{PM}_{2.5}: 182 \mu \mathrm{gm}^{-3}\right)$ and Shanghai $\left(\mathrm{PM}_{10}: 208 \mu \mathrm{gm}^{-3} ; \mathrm{PM}_{2.5}: 182 \mu \mathrm{gm}^{-3}\right)$, then 2 June for Suzhou $\left(\mathrm{PM}_{10}: 271 \mu \mathrm{gm}^{-3} ; \mathrm{PM}_{2.5}: 180 \mu \mathrm{gm}^{-3}\right)$, and finally 3 June for Nanjing $\left(\mathrm{PM}_{10}: 292 \mu \mathrm{gm}^{-3} ; \mathrm{PM}_{2.5}: 217 \mu \mathrm{gm}^{-3}\right)$, which is consistent with the crop harvest and biomass burning sequence from south to north. Compared with China ambient air quality standards (CAAQS) of $75 \mu \mathrm{gm}^{-3}$ for daily $\mathrm{PM}_{2.5}$ (Ministry of Environmental Protection of China, 2012), the average and maximum daily concentrations of the episode are 1.1 and 1.9 times for $\mathrm{PM}_{2.5}$. The particulate matter concentration level of the episode is comparable with observed results of other biomass burning events in the YRD area. K. Huang et al. (2012) observed a pollution episode from 28 May to 3 June 2009 (almost same as the time period of this study) and measured the $\mathrm{PM}_{2.5}$ and

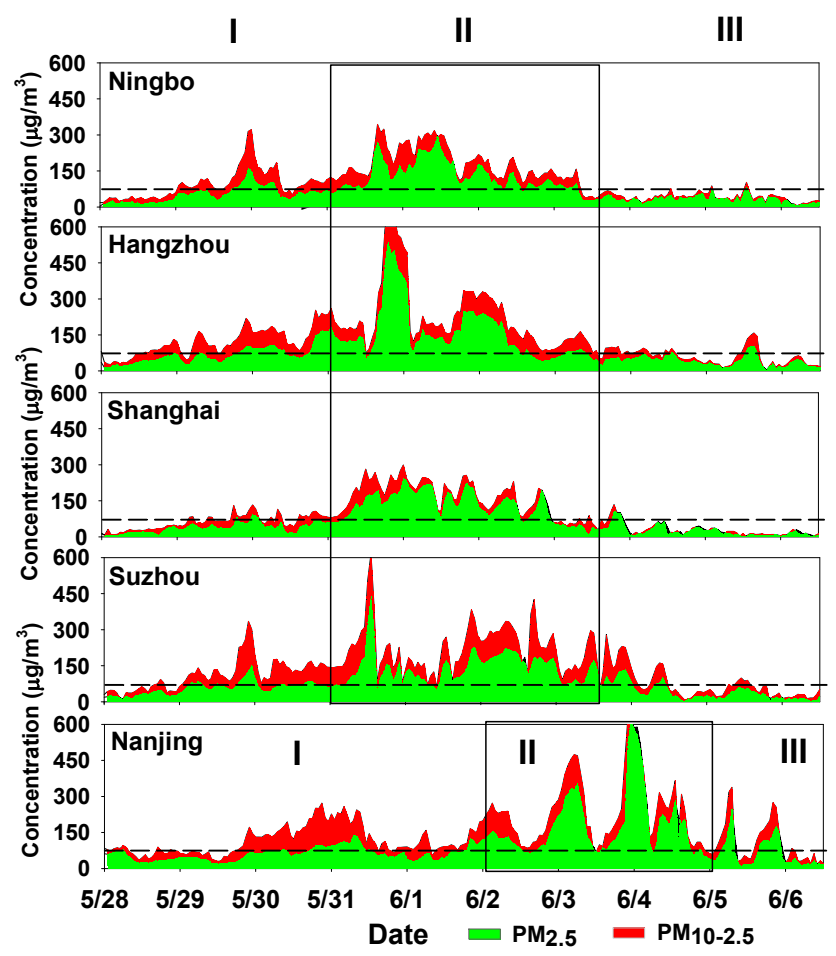

Fig. 2. Evolution of TEOM $\mathrm{PM}_{2.5}$ (green) and $\mathrm{PM}_{10-2.5}$ (red) mass concentrations during the monitoring period. The black lines show different phases described in the text. The horizontal long dash line represents the level of $75 \mu \mathrm{g} \mathrm{m}^{-3}$ (the China's national standard).

$\mathrm{PM}_{10}$ average concentrations of $84 \mu \mathrm{gm}^{-3}$ and $136 \mu \mathrm{gm}^{-3}$, respectively, in Shanghai. During the autumn biomass burning season (14-27 October 2009), Gao et al. (2012) measured the daily average and maximum $\mathrm{PM}_{2.5}$ concentrations in Nanjing, which were $200 \mu \mathrm{gm}^{-3}$ and $318 \mu \mathrm{gm}^{-3}$, respectively. Yin et al. (2011) summarized the official air pollution index (API) of six events in Nanjing during 2006-2009 and found that the corresponding daily maximum $\mathrm{PM}_{10}$ con-

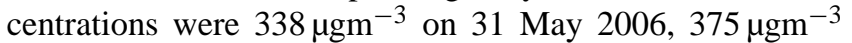

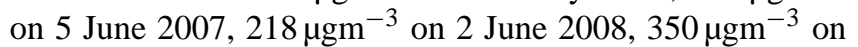
28 October 2008 and $435 \mu^{-3} m^{-3}$ on 8 November 2009. Although the crop residues burned in the summer harvest season (mainly straw of wheat and cole flowers) are different from those in autumn (mainly stalks of rice and corn), the PM concentration levels of the two harvest seasons have no substantial differences.

The daily average concentrations of $\mathrm{PM}_{2.5}$ species during the episode, which are from the laboratorial analytical result from the sampling filters, are reconstructed and shown in Fig. 3. The gap between the sum of reconstructed $\mathrm{PM}_{2.5}$ species and gravimetric mass, which is marked as "others" in Fig. 3, is $11 \%$ for the average of the three sites. Organic matter $(\mathrm{OM})$ is the highest value component, accounting for $40.1 \%$ of $\mathrm{PM}_{2.5}$ mass. During the episode, daily average and maximum concentrations of $\mathrm{OM}$ are 21 and $56 \mu \mathrm{gm}^{-3}$ 


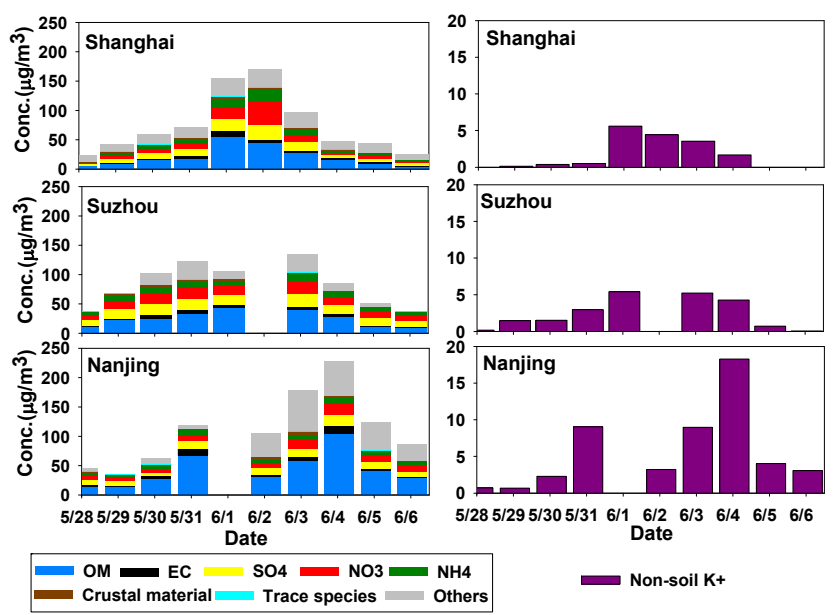

(a) (b)

Fig. 3. (a) Daily average concentrations of $\mathrm{PM}_{2.5}$ with chemical components. (b) Concentrations of non-soil soluble potassium $\left(\mathrm{K}^{+}\right)$in $\mathrm{PM}_{2.5}$. Organic matter $(\mathrm{OM})=1.55 \mathrm{OC}$, crustal material $=2.2 \mathrm{Al}+2.49 \mathrm{Si}+1.63 \mathrm{Ca}+2.42 \mathrm{Fe}+1.94 \mathrm{Ti}$, trace species $=\mathrm{As}+\mathrm{Br}+\mathrm{Cr}+\mathrm{Cu}+\mathrm{Mn}+\mathrm{Ni}+\mathrm{Pb}+\mathrm{Rb}+\mathrm{Se}+\mathrm{Sr}+\mathrm{Zn}$, non-soil $\mathrm{K}^{+}=\mathrm{K}^{+}-0.6 \mathrm{Fe}$, others $=\mathrm{PM}_{2.5}$ mass $\quad-\quad(\mathrm{OM}$ $+\mathrm{EC}+\mathrm{SO}_{4}+\mathrm{NO}_{3}+\mathrm{NH} 4+$ crustal material + trace species + non-soil $\mathrm{K}^{+}$). No data available for Hangzhou and Ningbo.

for Shanghai, 25 and $44 \mu \mathrm{gm}^{-3}$ for Suzhou, and 39 and $82 \mu \mathrm{gm}^{-3}$ for Nanjing. Inorganic ions like sulfate and nitrate are also important $\mathrm{PM}_{2.5}$ components. The daily average concentrations are in a range of $10-16 \mu \mathrm{gm}^{-3}$ for sulfate, and $10-15 \mu \mathrm{gm}^{-3}$ for nitrate. The maximum daily concentrations reach $24 \mathrm{\mu gm}^{-3}$ for sulfate and $42 \mu \mathrm{gm}^{-3}$ for nitrate. Increase in OM, sulfate and nitrate indicates that meteorological conditions might have enhanced the formation of secondary aerosols through accumulating and increasing the concentrations of gaseous precursors like $\mathrm{SO}_{2}, \mathrm{NO}_{\mathrm{x}}$ and VOCs, and their oxidation rates (Fu et al., 2008). As a marker of biomass burning, the daily average and maximum concentrations of non-soil $\mathrm{K}^{+}$are 1.6 and $5.6 \mu \mathrm{gm}^{-3}$ for Shanghai,

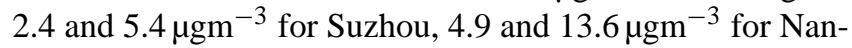
jing. The increase of non-soil $\mathrm{K}^{+}$concentrations indicates the contribution of biomass burning.

The heavy and widespread haze exhibits regional characteristics observed by all the three sites at the same episode. The episode can be divided into three phases: Phase (I) prepollution phase (28 May 00:00-30 May, 23:00), Phase (II) pollution phase (31 May 00:00-3 June, 12:00) and Phase (III) post-pollution phase (3 June 12:00-6 June, 12:00). For Nanjing site, Phase II commences between 2 June at 00:00 and 5 June at 00:00, one day later than that of other sites. The average concentrations of $\mathrm{PM}_{10}, \mathrm{PM}_{2.5}$ and major species, and the visual range for each phase are summarized in Table 1. The average PM concentrations increase 1.9-4-fold from Phases I to Phase II among the five sites. Maximum hourly concentrations for the five sites during the episode, all

occur in Phase II, reaching as high as $614 \mu \mathrm{gm}^{-3}$ for $\mathrm{PM}_{2.5}$ and $660 \mu \mathrm{gm}^{-3}$ for $\mathrm{PM}_{10}$. From Phase I to Phase II, the daily average concentrations among the five sites increase 1.8-3.6fold for OM and 1-3-fold for EC. Maximum daily OM con-

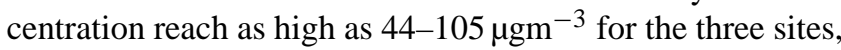
accounting for $35-43 \%$ of the $\mathrm{PM}_{2.5}$ mass. The increase in $\mathrm{OM}$ is the major cause of $\mathrm{PM}_{2.5}$ increase. Maximum daily non-soil $\mathrm{K}^{+}$concentration among the three sites reaches 5.4$18.3 \mu \mathrm{gm}^{-3}$ in Phase II, $3.5-15$ times that in Phase I. The concentrations of other water-soluble ions also increase in Phase II. Sulfate increases 1.2-2.5-fold with a maximum daily concentration of $19-20 \mu \mathrm{gm}^{-3}$ for the three sites. Nitrate increases 1.3-4.3-fold and the maximum daily concentration is $19-42 \mu \mathrm{gm}^{-3}$ for the five sites during Phase II. In order to investigate the sources of components increase, we compare the modeling species concentration distance between the base scenario with biomass burning and the scenario without any biomass burning for Phase II. It is found that after the injection of biomass burning emission, the concentration of OM and EC increase 2.2-6.6-fold and 1.0-3.7fold, respectively, while that of sulfate and nitrate only increase $2.0-4.2 \%$ and $19-38 \%$, respectively. The modeling results illustrates that the high concentration of OM and EC in Phase II are mainly from biomass burning. Nitrate is partly from biomass burning. The increase of sulfate shall be due to the accumulation of anthropogenic emissions under stagnant meteorological conditions rather than biomass burning emission.

\subsection{Pollution formation and transport}

Synoptic weather maps at the surface are given in Fig. 4. The maps show that from 31 May through 3 June, a tropical depression is formed from a low pressure center in the South China Sea, and another low pressure center in northern China is moving south on 31 May. Combined with the influence of three high pressure centers located in the western Pacific Ocean, northern China and southern China, uniform pressure prevails over most of eastern China. Then the high pressure center in South China moves east and the stagnant weather system under the control of this high pressure lasts until 2 June. At the same time the tropical depression is weakened to a low pressure center moving northeast and disappeared on 3 June. The uniform pressure on 1 June is responsible for the transport of air pollutants while the high pressure on 2 June enhances the accumulation of pollutants. The weather system in Nanjing, being the furthest west inland, changes one day earlier than other cities as the weather system moves from west to east. From noon of 3 June, a western wind shortwave trough appears around the Shanghai area, and there is precipitation during 4-6 June that acts as a cleaning agent, although the thick cloud cover might have reduced mixing depth. The synoptic weather is conducive to pollutant accumulation during Phase II, and clean-out in Phase III. 
Table 1. PM mass concentration, visual range and meteorological parameters for three phases of the pollution episode.

\begin{tabular}{|c|c|c|c|c|c|c|}
\hline \multirow[t]{2}{*}{ Index } & \multirow[t]{2}{*}{ Phase* } & \multicolumn{5}{|c|}{ Sampling sites } \\
\hline & & Ningbo & Hangzhou & Shanghai & Suzhou & Nanjing \\
\hline \multirow[t]{3}{*}{ PM mass $\left(\mu \mathrm{gm}^{-3}\right)$} & $\mathrm{I}$ & $\mathrm{PM}_{10}: 91, \mathrm{PM}_{2.5}: 51$ & $\mathrm{PM}_{10}: 115, \mathrm{PM}_{2.5}: 64$ & $\mathrm{PM}_{10}: 60, \mathrm{PM}_{2.5}: 37$ & $\mathrm{PM}_{10}: 109, \mathrm{PM}_{2.5}: 55$ & $\mathrm{PM}_{10}: 114, \mathrm{PM}_{2.5}: 60$ \\
\hline & II & $\mathrm{PM}_{10}: 176, \mathrm{PM}_{2.5}: 125$ & $\mathrm{PM}_{10}: 225, \mathrm{PM}_{2.5}: 157$ & $\mathrm{PM}_{10}: 160, \mathrm{PM}_{2.5}: 128$ & $\mathrm{PM}_{10}: 220, \mathrm{PM}_{2.5}: 139$ & $\mathrm{PM}_{10}: 240, \mathrm{PM}_{2.5}: 180$ \\
\hline & III & $\mathrm{PM}_{10}: 41, \mathrm{PM}_{2.5}: 32$ & $\mathrm{PM}_{10}: 58, \mathrm{PM}_{2.5}: 41$ & $\mathrm{PM}_{10}: 28, \mathrm{PM}_{2.5}: 25$ & $\mathrm{PM}_{10}: 73, \mathrm{PM}_{2.5}: 40$ & $\mathrm{PM}_{10}: 99, \mathrm{PM}_{2.5}: 64$ \\
\hline \multirow{3}{*}{$\begin{array}{l}\mathrm{PM}_{2.5} \text { species } \\
\left(\mu \mathrm{gm}^{-3}\right)\end{array}$} & $\mathrm{I}$ & N/A & N/A & $\mathrm{K}^{+}: 0.3, \mathrm{OM}: 12, \mathrm{EC}: 2$ & $\mathrm{~K}^{+}: 1.5, \mathrm{OM}: 23, \mathrm{EC}: 4$ & $\mathrm{~K}^{+}: 3.2, \mathrm{OM}: 31, \mathrm{EC}: 5$ \\
\hline & II & N/A & N/A & $\mathrm{K}^{+}: 4.5, \mathrm{OM}: 43, \mathrm{EC}: 6$ & $\mathrm{~K}^{+}: 5.3, \mathrm{OM}: 42, \mathrm{EC}: 4$ & $\mathrm{~K}^{+}: 14, \mathrm{OM}: 82, \mathrm{EC}: 10$ \\
\hline & III & N/A & N/A & $\mathrm{K}^{+}: 0.6, \mathrm{OM}: 10, \mathrm{EC}: 2$ & $\mathrm{~K}^{+}: 1.7, \mathrm{OM}: 16, \mathrm{EC}: 3$ & $\mathrm{~K}^{+}: 3.5, \mathrm{OM}: 35, \mathrm{EC}: 4$ \\
\hline \multirow[t]{3}{*}{ Visual range $(\mathrm{km})$} & I & 13.9 & 6.2 & 13.5 & 8.5 & 11.0 \\
\hline & II & 10.0 & 5.0 & 3.7 & 3.8 & 5.4 \\
\hline & III & 10.4 & 4.9 & 8.7 & 4.9 & 4.2 \\
\hline \multirow[t]{3}{*}{$\mathrm{RH}(\%)$} & I & 58 & 59 & 56 & 56 & 50 \\
\hline & II & 65 & 65 & 61 & 61 & 50 \\
\hline & III & 84 & 96 & 79 & 78 & 77 \\
\hline \multirow[t]{3}{*}{ Mixing depth (m) } & $\mathrm{I}$ & 458 & 505 & 461 & 541 & 489 \\
\hline & II & 240 & 391 & 295 & 399 & 582 \\
\hline & III & 248 & 283 & 319 & 405 & 627 \\
\hline \multirow[t]{3}{*}{ Wind speed $\left(\mathrm{ms}^{-1}\right)$} & $\mathrm{I}$ & 1.6 & 1.6 & 1.3 & 1.3 & 1.5 \\
\hline & II & 0.9 & 2.5 & 1.1 & 1.4 & 1.4 \\
\hline & III & 0.9 & 1.2 & 1.4 & 1.4 & 1.9 \\
\hline
\end{tabular}

pre-pollution phase (28 May 00:00-1 June 23:00, marked I), pollution phase (2 June 00:00 to 4 June 23:00, marked II) and post-pollution phase (5 June 00:00 to 6 June 12:00, marked III).

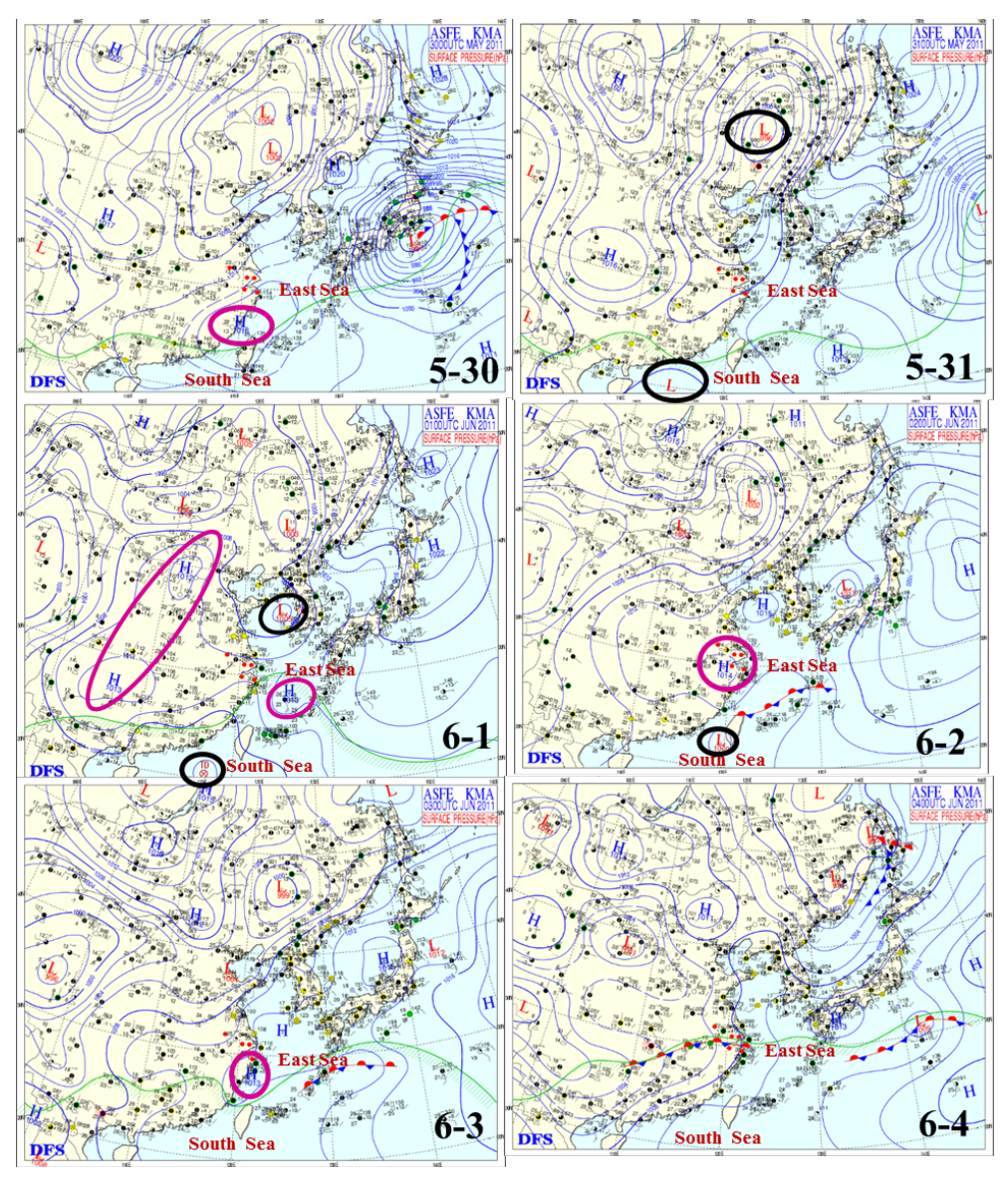

Fig. 4. Surface weather patterns over eastern China from 30 May to 4 June 2011. Black circle represents the low pressure center, pink circle represents the high pressure center, and red dot denotes the observation site. 


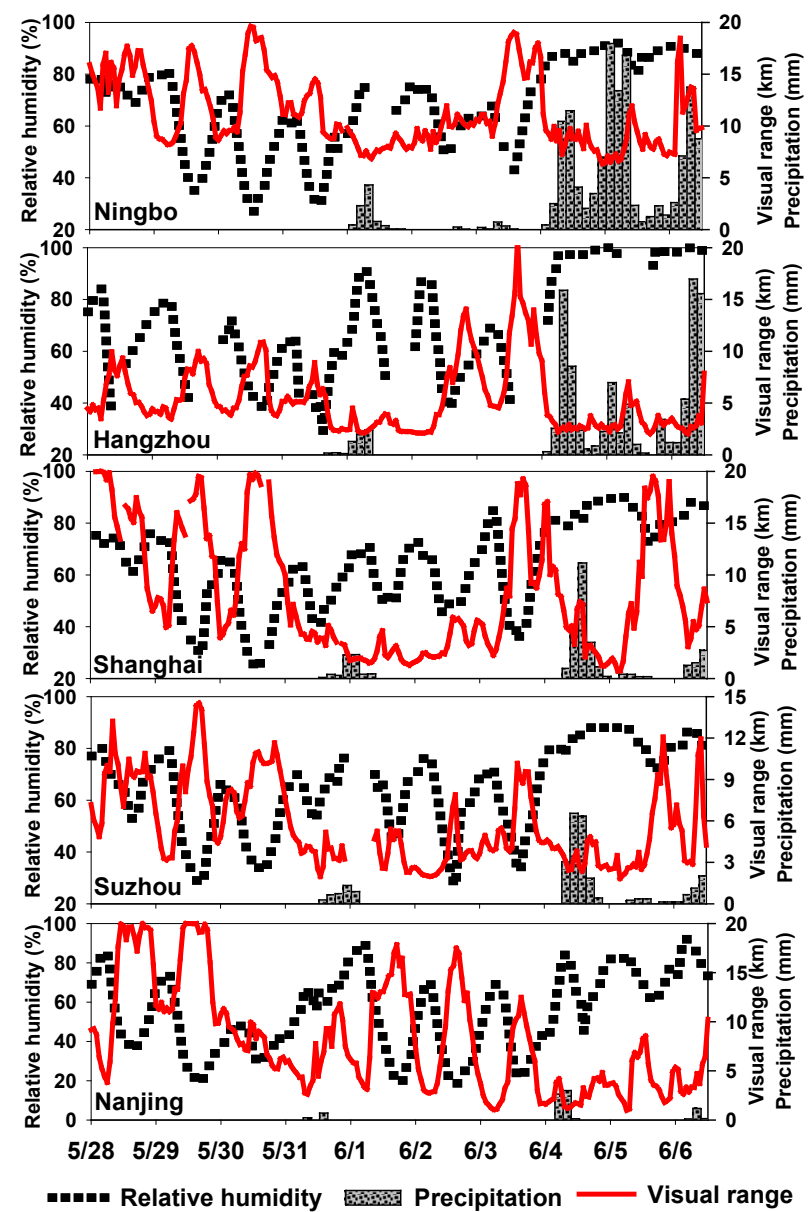

Fig. 5. Relative humidity (black dots), visual range (red line) and precipitation (shaded bar) at each site from 28 May to 6 June 2011.

The temporal variation of relative humidity, visual range, wind speed, precipitation and mixing depth (shown in Fig. 5 and 6) differ among Phases I, II, and III, as shown in Table 1. The major meteorological parameters of the three phases are summarized as follows:

- Phase I (Pre-pollution): there is no precipitation during this period. Average visual range is $6.2-13.9 \mathrm{~km}$ with an RH of $50-61 \%$. Mixing depth is in the range of $458-505 \mathrm{~m}$ and wind speed varies between 1.3 and $1.6 \mathrm{~ms}^{-1}$. The variation in wind speed is consistent with the trend in mixing depth.

- Phase II (pollution): the precipitation is only $2-5 \mathrm{~mm}$, with RH increased by 5-7\% except for the Nanjing site, with no change in $\mathrm{RH}$ as compared to Phase I. The visual range is $3.7-10 \mathrm{~km}$, about $1.2-9.8 \mathrm{~km}$ lower than that of Phase I (shown in Fig. 5). The mixing depth is $240-399 \mathrm{~m}, 114-218 \mathrm{~m}$ lower than that of Phase I. The average mixing depth of Nanjing site during Phase II is $582 \mathrm{~m}$, which is $93 \mathrm{~m}$ higher than that of Phase I, indicating the meteorological condition is

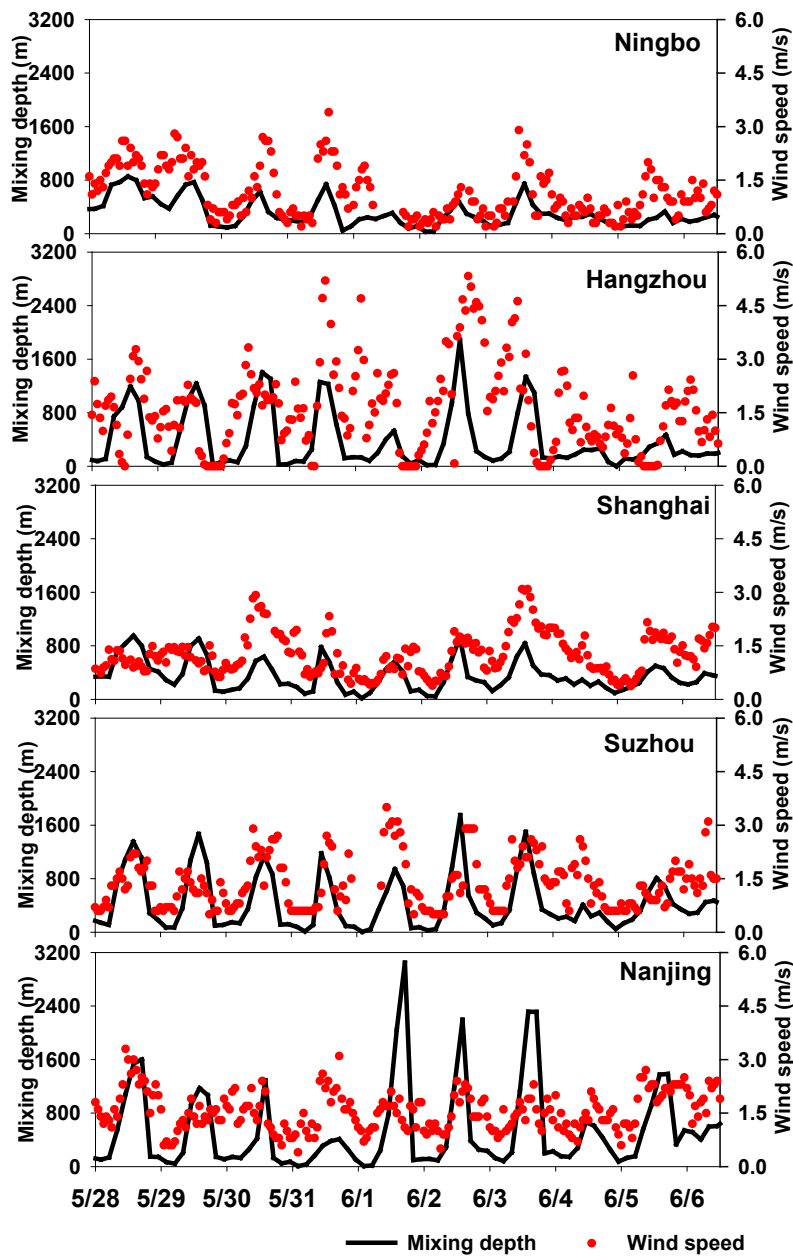

Fig. 6. Mixing depths (black lines) and wind speeds (red dots) at each monitoring site from 28 May to 6 June 2011.

actually better for Nanjing site. Minimum $3 \mathrm{~h}$ mixing depth is as low as $5-30 \mathrm{~m}$ for five sites. For Shanghai, Nanjing and Ningbo, the wind speeds are 0.2, 0.1 and $0.7 \mathrm{~ms}^{-1}$ lower than those of Phase I, respectively. For Suzhou and Hangzhou they are 0.1 and $0.9 \mathrm{~ms}^{-1}$ higher than those of Phase I. Ambient RH shows typical diurnal variation (shown in Fig. 5), usually with the peak value at midnight and valley value at noon due to sunshine. However, the visibility is affected both by the PM pollution level and RH value. For all the sites except for Nanjing, the PM pollution in Phase II was accumulated without notable diurnal variation, resulting in the visibility under low value continuously. For the Nanjing site, the PM pollution in Phase II also shows diurnal change, the same as that of RH variation. Hence the visibility in Nanjing site also varied diurnally during Phase II.

- Phase III (post-pollution): precipitation is $10-18 \mathrm{~mm}$ during this phase, much higher than Phases I and II, 

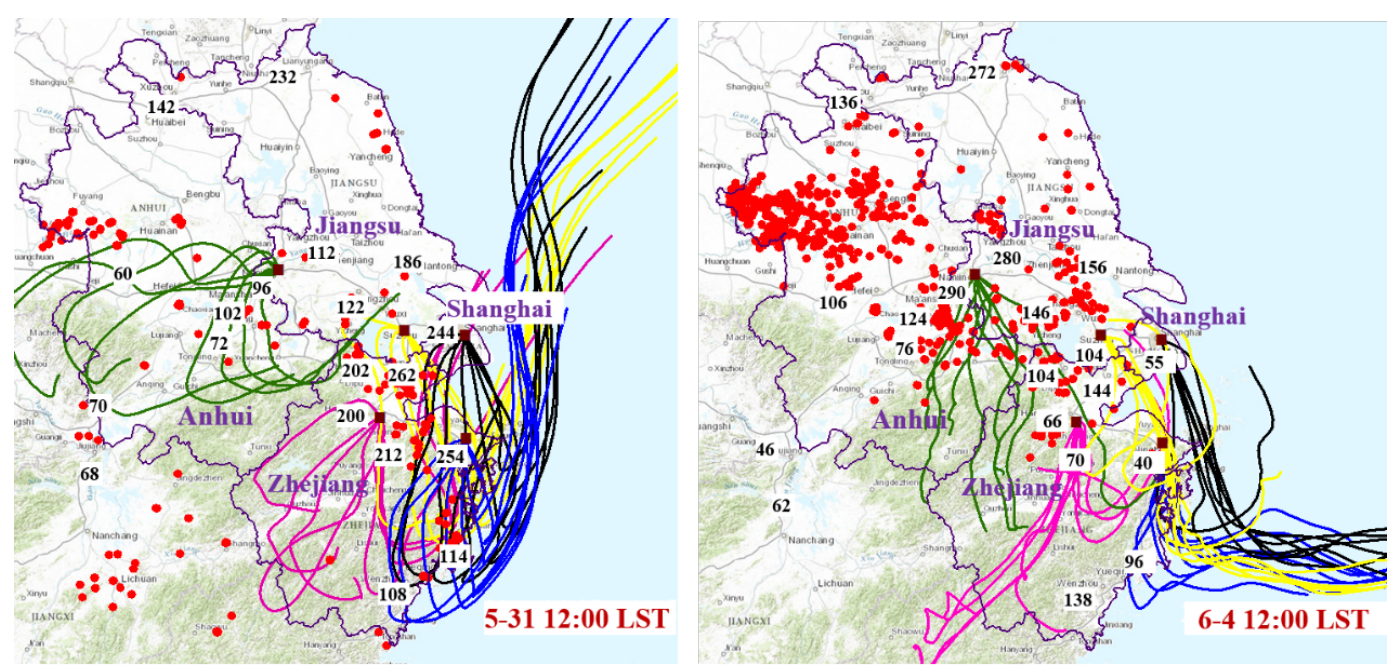

Fig. 7. HYSPLIT $24 \mathrm{~h}$ back-trajectories at $100 \mathrm{~m}$ a.g.l. originating at each monitoring site (black squares) calculated every $3 \mathrm{~h}$ beginning at 12:00 LST and ending at 09:00 LST the previous day. Red dots represent the satellite-detected fires (FIRMS, Davies et al., 2009). Numbers are the daily average $\mathrm{PM}_{10}$ mass concentrations from air quality monitoring (http://datacenter.mep.gov.cn/report/air_daily/air_dairy.jsp). Back-trajectory colors are Black - Shanghai, Blue - Ningbo, Pink - Hangzhou, Yellow - Suzhou, Green - Nanjing.

except for Nanjing, with precipitation less than $5 \mathrm{~mm}$. Average RH is as high as $77-96 \%$. Although the PM concentration is quite low, fogs occur in Nanjing and medium-heavy rain events occur in other sites, which reduce the visual range (Winkler, 1988; Elias et al., 2009).

Back trajectories along with fire locations and $\mathrm{PM}_{10}$ concentrations of two typical days are shown in Fig. 7. MODIS cannot detect fires due to high cloud cover on 1 June and 5 June (http://modis-atmos.gsfc.nasa.gov/IMAGES), hence 4 June is selected to represent Phase II for Nanjing while 31 May for the other four sites. On 31 May, fires are mainly located near Hangzhou Bay in northern Zhejiang Province, the southern border of the Shanghai municipality, and southern Jiangsu Province around Tai Lake, only limited fires are found in the area close to Nanjing. For Shanghai, Hangzhou, Ningbo and Suzhou, the main air flow is from the south, mixing with the pollutants from fires along the path. As a result, the main hot spots of $\mathrm{PM}_{10}$ pollution concentrated in the area of Shanghai and northern Zhejiang Province with daily average concentration over $200 \mu \mathrm{gm}^{-3}$. The situation changes on 4 June. Compared with that on 31 May, most fire spots are located in the north (i.e., central Anhui Province and southern Jiangsu Province). The air flow is from the south for the five sites. As a result, high $\mathrm{PM}_{10}$ concentrations occur in Jiangsu Province. The daily $\mathrm{PM}_{2.5}$ concentrations in Nanjing are between 150 and $290{\mu g m^{-3}}^{-3}$, followed by Suzhou $\left(104 \mu \mathrm{gm}^{-3}\right)$. In contrast, the concentrations at the other three sites are all less than $70 \mu \mathrm{gm}^{-3}$, and not affected by the biomass burning. With individual monitoring site, previous studies only reported the possible locations of the biomass burning that affected the air quality in Nan- jing. Zhu et al. (2012) found that the pollution of Nanjing was caused by the transport from the north-central area of Jiangsu Province and northeastern area of Anhui Province on 29 October 2008. Gao et al. (2012) concluded that the source area was in the central area of Jiangsu Province during 1427 October 2009. Su et al. (2012) found Nanjing was affected by both Jiangsu Province and Anhui Province on 2 November 2010. Our findings for the biomass burning regions that affected Nanjing agree with the above studies, indicating that the crop locations might not have changed in recent years.

\subsection{Contributions of biomass burning to particulate pollution}

The emission source profiles are crucial for the calculation of receptor modeling such as CMB. Table 2 summarizes the mass ratios of $\mathrm{PM}_{2.5}$ to $\mathrm{K}^{+}, \mathrm{OC}$ to $\mathrm{K}^{+}$and $\mathrm{EC}$ to $\mathrm{K}^{+}$for biomass burning source profiles in the literature. The measured ratios from different studies vary from 4.1 to 175.4 for $\mathrm{PM}_{2.5} / \mathrm{K}^{+}$ratio, from 0.8 to 121.1 for the $\mathrm{OC} / \mathrm{K}^{+}$ratio and from 0.5 to 5.3 for the $\mathrm{EC} / \mathrm{K}^{+}$ratio. Fuel is one of the dominant factors causing the large variations. However, even with the same burning fuel such as wheat straw, the ratios are still with large ranges, that is, the $\mathrm{PM}_{2.5} / \mathrm{K}^{+}$ ratio varied from 10.1 in China to 4.1 in the United States, and the $\mathrm{OC} / \mathrm{K}^{+}$ratio varied from 3.9 in China to 0.8 in the United States. This variability potentially reflects differences in combustion conditions and sampling methods. Cheng et al. (2013) found that the ratio of OC to levoglucosan (another biomass burning marker) also varied between 4.0 and 46.9 due to similar reasons. For the summer harvest period of this study, wheat straw constitutes most of the agricultural residues in the YRD region (Yin et al., 2011), and the closest 


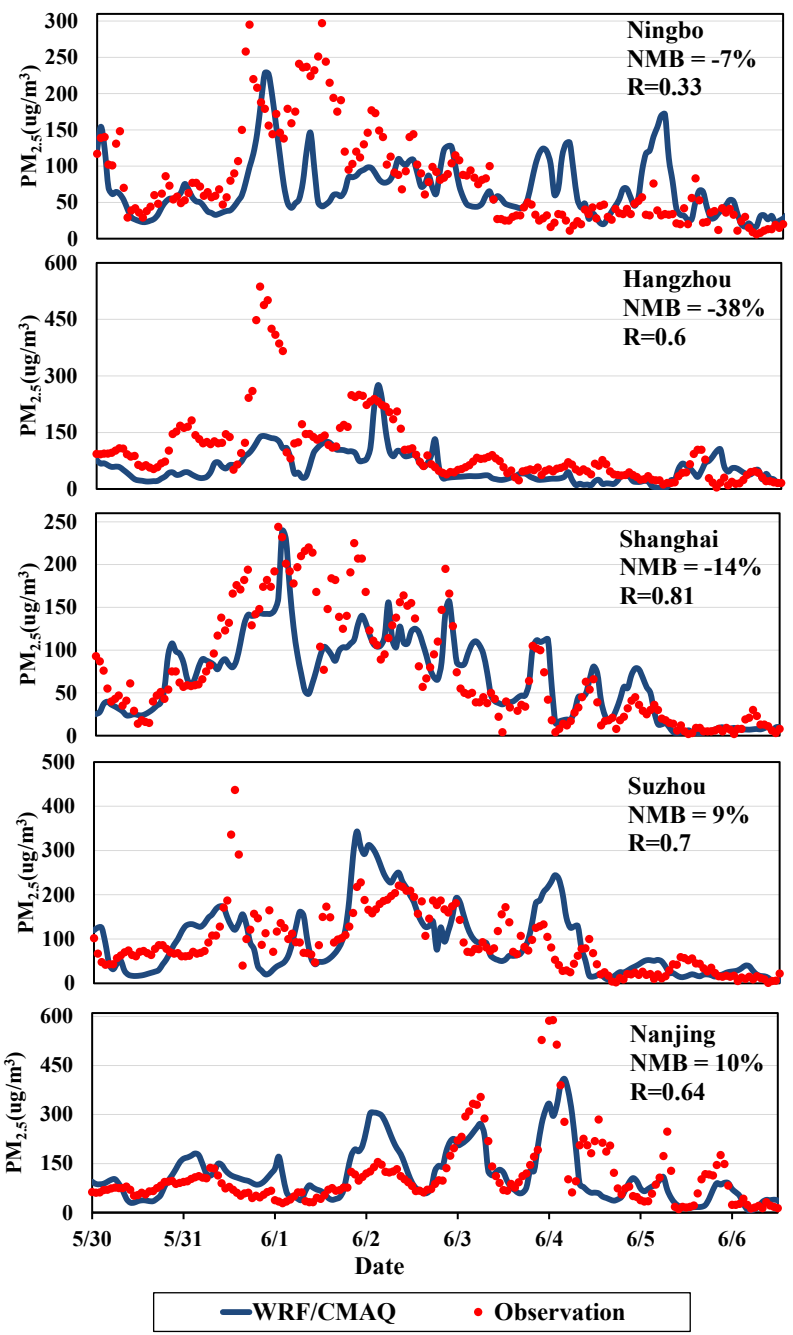

Fig. 8. Comparison of CMAQ simulations (blue lines) and TEOMmeasured (red dots) hourly $\mathrm{PM}_{2.5}$ mass concentrations. NMB means normalized mean bias. $R$ means the correlation coefficient.

approximation to these biomass burnings are the measurements by $\mathrm{Li}$ et al. (2007), which were conducted in nearby Shandong Province. The mass ratios of $\mathrm{PM}_{2.5} / \mathrm{K}^{+}, \mathrm{OC} / \mathrm{K}^{+}$ and $\mathrm{EC} / \mathrm{K}^{+}$used in this study are thus $10.1,3.9$ and 0.8 , respectively.

For the WRF/CMAQ model, an important prerequisite is that the model simulation could reproduce the pollution episode well at the base case. First the meteorological parameter of WRF model are compared with the observation data set of National climate data center (NCDC) of the US. The average biases between the two data sets are acceptable with $0.44 \mathrm{~ms}^{-1}$ for wind speed, $1.03^{\circ}$ for wind direction, $-0.55 \mathrm{~K}$ for temperature and $0.26 \mathrm{gkg}^{-1}$ for relative humidity. Then the modeled and measured hourly $\mathrm{PM}_{2.5}$ (TEOM) at each of the five sites are compared in Fig. 8, indicating that CMAQ model gives the same temporal trends and pollution levels as measurements. The normalized mean biases (NMB) are
$-7 \%$ for Ningbo, $-38 \%$ for Hangzhou, $-14 \%$ for Shanghai, $-9 \%$ for Suzhou and $10 \%$ for Nanjing, mostly due to pollution peak bias during Phase II. Several outliers from the modeling results are found for the sites of Hangzhou and Ningbo, resulting the correlation coefficient $(R)$ below 0.6. The simulated pollution peak on 1 June in Hangzhou is much lower than the observed value, which results in the model underestimating the measured values by $38 \%$. For Ningbo, although the NMB is only $-7 \%$, the observed accumulated peak at 1 June is not fully reproduced. The better simulation performance during Phases I and III, which are less effected by biomass burning, illustrates that the non-biomass burning anthropogenic emission inventory and its distribution is reasonable and acceptable. Conversely, the outliers during the Phase II indicates that some uncertainties of the biomass burning emission amount and its spatial distribution still exists, especially for the time with thick cloud cover which will affect the quality of satellite information.

The contribution of biomass burning to mass concentrations of $\mathrm{PM}_{2.5}$, OC and EC based on the CMAQ model and ambient measurements are compared in Table 3. Over all, the model estimates of biomass burning contribution to $\mathrm{PM}_{2.5}$ concentrations are comparable with the measurement results, while the modeling results for $\mathrm{OC}$ and $\mathrm{EC}$ are higher than the measurement results. One of the reasons is that the CMAQ model can include the contribution of primary gaseous precursors of biomass burning to secondary aerosols in $\mathrm{PM}_{2.5}$. Another reason is that the air quality transport model and receptor model use different source apportionment methods, as well as different inputs. The following discussions are based on the modeling results. Among the five sites, Nanjing is most affected by biomass burning during the episode, followed by Suzhou, Shanghai, Ningbo, and Hangzhou. For the Nanjing site, the contribution of biomass burning is $48 \%\left(64.5 \mu \mathrm{gm}^{-3}\right)$ for $\mathrm{PM}_{2.5}, 83 \%\left(29.4 \mu \mathrm{gm}^{-3}\right)$ for OC, and $61 \%\left(5.6 \mu \mathrm{gm}^{-3}\right)$ for EC; for the Suzhou site, biomass burning contributes $43 \%\left(49.2 \mu \mathrm{gm}^{-3}\right)$ of $\mathrm{PM}_{2.5}$, $86 \%\left(28.2 \mu \mathrm{gm}^{-3}\right)$ of $\mathrm{OC}$, and $78 \%\left(5.8 \mu \mathrm{gm}^{-3}\right)$ of $\mathrm{EC}$; for the Shanghai site, $35 \%\left(28.1 \mu \mathrm{gm}^{-3}\right)$ of $\mathrm{PM}_{2.5}, 69 \%$

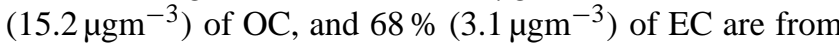
biomass burning; and for the Ningbo site, biomass burning contributes $41 \%\left(30.0 \mu \mathrm{gm}^{-3}\right)$ of $\mathrm{PM}_{2.5}, 86 \%\left(18.1 \mu \mathrm{gm}^{-3}\right)$ of OC, $71 \%\left(3.7 \mu \mathrm{gm}^{-3}\right)$ of EC. The contribution of biomass burning to $\mathrm{PM}_{2.5}$ concentrations in Hangzhou site is lowest, only $23 \%$, which might be due to underestimate of modeling results as shown in Fig. 8.

Based on the WRF/CMAQ modeling results, the contribution of biomass burning in each region is further analyzed, as shown in Fig. 9. It is found that biomass burning of Jiangsu Province and Anhui Province is the major contributor to the Nanjing site, which is consistent with previous studies (Su et al., 2012; Zhu et al., 2012). Jiangsu and Anhui contribute $27 \%$ and $15 \%$ of $\mathrm{PM}_{2.5}$ mass concentrations in Nanjing. The widely distributed burning fields in Jiangsu and Anhui Province make Nanjing the most influenced site 
Table 2. Mass ratio of $\mathrm{PM}_{2.5}$, $\mathrm{OC}$ and $\mathrm{EC}$, normalized to water-soluble potassium $\left(\mathrm{K}^{+}\right)$in literature

\begin{tabular}{|c|c|c|c|c|}
\hline Observation & Biomass type & Location & Mass ratio & Reference \\
\hline \multirow{7}{*}{$\mathrm{PM}_{2.5} / \mathrm{K}^{+}$} & \multirow[t]{2}{*}{ Wheat straw } & Shandong, China & $10.1^{*}$ & Li et al. (2007) \\
\hline & & Washington, US & 4.07 & Hays et al. (2005) \\
\hline & \multirow[t]{2}{*}{ Rice straw } & South Asia & 50 & Sheesley et al. (2003) \\
\hline & & Washington, US & 175.4 & Hays et al. (2005) \\
\hline & Maize stover & Shandong, China & 11.8 & Li et al. (2007) \\
\hline & \multirow[t]{2}{*}{ Agricultural residues } & California, US & 14.2 & SPECIATE4.3 (2009) \\
\hline & & Global average & $9.1-30$ & Andreae and Merlet (2001) \\
\hline \multirow{7}{*}{$\mathrm{OC} / \mathrm{K}^{+}$} & \multirow[t]{2}{*}{ Wheat straw } & Shandong, China & $3.9^{*}$ & Li et al. (2007) \\
\hline & & Washington, US & 0.8 & Hays et al. (2005) \\
\hline & \multirow{2}{*}{ Rice straw } & South Asia & 26.3 & Sheesley et al. (2003) \\
\hline & & Washington, US & 121.1 & Hays et al. (2005) \\
\hline & Maize stover & Shandong, China & 3.9 & Li et al. (2007) \\
\hline & \multirow[t]{2}{*}{ Agricultural residues } & California, US & 5.5 & SPECIATE4.3 (2009) \\
\hline & & Global average & $7.7-25.8$ & Andreae and Merlet (2001) \\
\hline \multirow[t]{7}{*}{$\mathrm{EC} / \mathrm{K}^{+}$} & \multirow[t]{2}{*}{ Wheat straw } & Shandong, China & $0.8^{*}$ & Li et al. (2007) \\
\hline & & Washington, US & 0.5 & Hays et al. (2005) \\
\hline & \multirow[t]{2}{*}{ Rice straw } & South Asia & 1.6 & Sheesley et al. (2003) \\
\hline & & Washington, US & 2.3 & Hays et al. (2005) \\
\hline & Maize stover & Shandong, China & 0.4 & Li et al. (2007) \\
\hline & \multirow{2}{*}{ Agricultural residues } & California, US & 1.6 & SPECIATE4.3 (2009) \\
\hline & & Global average & $1.6-5.3$ & Andreae and Merlet (2001) \\
\hline
\end{tabular}

* The value used in this study.

Table 3. Contribution of biomass burning to mass concentrations of $\mathrm{PM}_{2.5}$, OC and EC

\begin{tabular}{|c|c|c|c|c|c|c|c|}
\hline \multirow[t]{2}{*}{ Site } & \multirow[t]{2}{*}{ Method } & \multicolumn{2}{|c|}{$\mathrm{PM}_{2.5}($ Average $\pm \mathrm{SD})$} & \multicolumn{2}{|c|}{ OC (Average \pm SD) } & \multicolumn{2}{|c|}{$\mathrm{EC}($ Average $\pm \mathrm{SD})$} \\
\hline & & Value & Ratio $^{b}$ & Value & Ratio $^{b}$ & Value & Ratio $^{b}$ \\
\hline & & $\left(\mu \mathrm{gm}^{-3}\right)$ & $(\%)$ & $\left(\mu \mathrm{gm}^{-3}\right)$ & $(\%)$ & $\left(\mu \mathrm{gm}^{-3}\right)$ & $(\%)$ \\
\hline Ningbo $^{a}$ & WRF/CMAQ & $30.0 \pm 8.0$ & $41 \pm 5$ & $18.1 \pm 4.1$ & $86 \pm 5$ & $3.7 \pm 0.9$ & $71 \pm 9$ \\
\hline Hangzhou $^{\mathrm{a}}$ & WRF/CMAQ & $17.6 \pm 16.5$ & $23 \pm 13$ & $7.8 \pm 8.8$ & $56 \pm 28$ & $1.5 \pm 1.8$ & $38 \pm 26$ \\
\hline \multirow[t]{2}{*}{ Shanghai } & Measurement & $29.2 \pm 23.4$ & $26 \pm 15$ & $10.4 \pm 8.3$ & $48 \pm 26$ & $2.1 \pm 1.7$ & $44 \pm 27$ \\
\hline & WRF/CMAQ & $28.1 \pm 10.4$ & $35 \pm 5$ & $15.2 \pm 4.5$ & $69 \pm 8$ & $3.1 \pm 0.9$ & $68 \pm 9$ \\
\hline \multirow[t]{2}{*}{ Suzhou } & Measurement & $35.7 \pm 21.2$ & $30 \pm 13$ & $12.7 \pm 7.5$ & $60 \pm 22$ & $2.5 \pm 1.5$ & $56 \pm 35$ \\
\hline & WRF/CMAQ & $49.2 \pm 28.0$ & $43 \pm 8$ & $28.2 \pm 14.5$ & $86 \pm 7$ & $5.8 \pm 3.0$ & $78 \pm 9$ \\
\hline \multirow[t]{2}{*}{ Nanjing } & Measurement & $74.9 \pm 48.4$ & $47 \pm 19$ & $26.6 \pm 17.2$ & $71 \pm 16$ & $5.3 \pm 3.4$ & $70 \pm 22$ \\
\hline & WRF/CMAQ & $64.5 \pm 26.7$ & $48 \pm 8$ & $29.4 \pm 13.3$ & $83 \pm 7$ & $5.6 \pm 2.8$ & $61 \pm 13$ \\
\hline Average & - & 41.2 & 37 & 18.6 & 70 & 3.7 & 61 \\
\hline
\end{tabular}

by biomass burning. Suzhou is located in the center of the YRD region and is mainly affected by the biomass burning from Zhejiang Province and Shanghai municipality. The local biomass burning of Jiangsu Province only contributes $3 \%$ of $\mathrm{PM}_{2.5}$ in Suzhou, as Suzhou is located in southern Jiangsu Province and the dominant air flow during the episode is ori- ented from the south, where Zhejiang Province and Shanghai municipality are located. Shanghai is mainly affected by local biomass burning, which contributed $16 \%$ of $\mathrm{PM}_{2.5}$ mass concentrations. The contributions from biomass burning in Zhejiang Province are also important, accounting for $11 \%$ of $\mathrm{PM}_{2.5}$ mass. Different from other sites, Ningbo and 


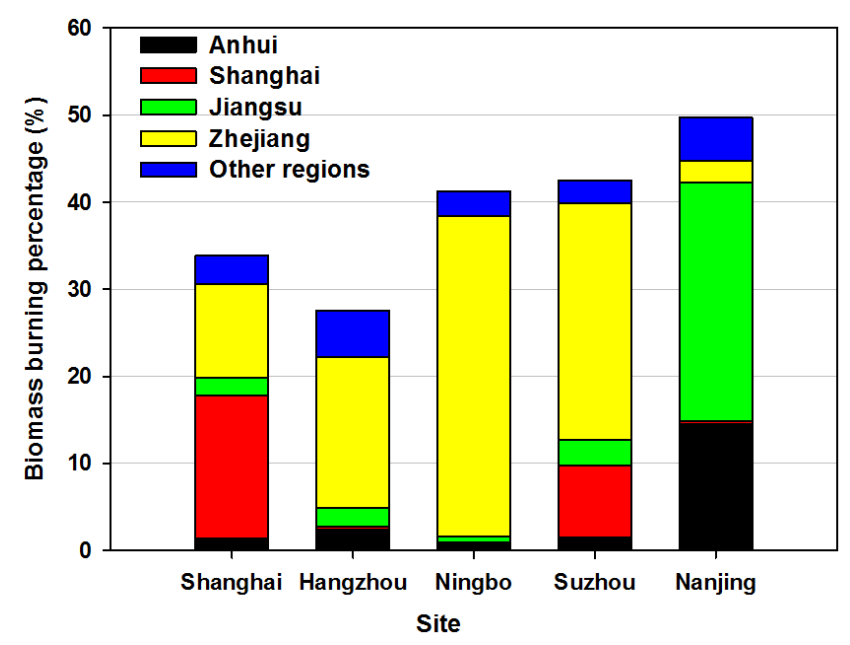

Fig. 9. Percentage contribution of biomass burning to $\mathrm{PM}_{2.5}$ mass concentration. Location of each region is shown in Fig. 1. The remaining percentage represents the contribution of other emission sources.

Hangzhou are mainly affected by local biomass burning in Zhejiang Province. The local burning contributes $37 \%$ and $17 \%$ of $\mathrm{PM}_{2.5}$ mass for Ningbo and Hangzhou, respectively.

Overall, the average percentage contribution of biomass burning is $37 \%\left(41 \mathrm{\mu gm}^{-3}\right)$ for $\mathrm{PM}_{2.5}, 70 \%\left(19 \mu \mathrm{gm}^{-3}\right)$ for $\mathrm{OC}$ and $61 \%\left(4 \mathrm{\mu gm}^{-3}\right)$ for EC for the five sites during the episode, indicating that biomass burning has significant impacts on $\mathrm{PM}_{2.5}$ mass, especially for the carbonaceous species which can extinguish incident light efficiently. Based on the WRF/CMAQ simulation results, the average $\mathrm{PM}_{2.5}$ concentration for the inner YRD domain is $72.3{\mu g m^{-3}}^{-3}$ during the pollution episode. If the biomass burning is completely forbidden, the average $\mathrm{PM}_{2.5}$ concentration will be reduced to $35.5{\mu \mathrm{gm}^{-3}}^{-3}$, only $49 \%$ of base case with biomass burning. Then we multiply the $\mathrm{PM}_{2.5}$ concentration with population at each grid cell in the YRD domain to calculate the changes of population exposure. As a result, the PM2.5 exposure level for the YRD domain will decrease $47 \%$. Significant health benefit due to particulate matter is expected through the efficient biomass burning ban for the YRD region.

Although emissions of biomass burning only account for $2.7 \%$ of the annual anthropogenic $\mathrm{PM}_{2.5}$ emissions in the YRD region (Huang et al., 2011), it is intensively emitted in a short period after harvest, which rapidly increases $\mathrm{PM}_{2.5}$ concentration and decreases visibility, resulting in a threat to public health and hot spot of social attention every year (http: //www.chinanews.com/gn/2012/06-12/3958032.shtml). Furthermore, the contribution of biomass burning from subregions confirms that biomass burning could indeed affect both local and regional $\mathrm{PM}_{2.5}$ concentrations by atmospheric transport. Regional joint control of biomass burning shall be implemented with efforts and cooperation of all cities.

\section{Conclusions}

Open biomass burning after harvest season could result in severe air pollution and haze issues. In the haze event observed in the summer of 2011, the average and maximum daily $\mathrm{PM}_{2.5}$ concentrations reached $82 \mu \mathrm{gm}^{-3}$ and $144 \mu \mathrm{gm}^{-3}$, respectively. A sharp increase in $\mathrm{PM}_{2.5}, \mathrm{~K}^{+}$and carbonaceous aerosol during pollution episodes confirmed the contribution of biomass burning to elevated PM concentrations. Stagnant meteorological conditions, caused by a stable high pressure system during 31 May-2 June, combined with high relative humidity and low mixing depth, enhanced the accumulation of air pollutants and caused the formation of haze.

The impacts of biomass open burning on air pollution were quantified using both air quality modeling and measurement methods. It was found that biomass burning contributed $37 \%$ $\left(41 \mathrm{ggm}^{-3}\right)$ of $\mathrm{PM}_{2.5}, 70 \%\left(19 \mu \mathrm{gm}^{-3}\right)$ of $\mathrm{OC}$ and $61 \%$ $\left(4 \mu \mathrm{gm}^{-3}\right)$ of EC, indicating that biomass burning had significantly affected the air quality in the YRD region. The results of source apportionment also implied that the impact of biomass open burning is regional, due to the substantial inter-province transport of air pollutants. Satellite-detected fire spots, back-trajectory analysis and air model simulation can be integrated to identify the locations where the biomass is burned and its transport path. This exercise could be helpful to improve the understanding of heavy pollution episodes.

The results of this study also indicate that the reduction of biomass burning for the YRD region requires regionaljoint management and control strategies. If the biomass open burning is completely banned, the average $\mathrm{PM}_{2.5}$ concentration for the YRD region would decrease $51 \%$, and accordingly the exposure level would decrease $47 \%$ during the post-harvest season.

\section{Supplementary material related to this article is available online at http://www.atmos-chem-phys.net/14/ 4573/2014/acp-14-4573-2014-supplement.pdf.}

Acknowledgements. This work is supported by the National Natural Science Foundation of China (21221004 \& 41227805), MEP's Special Funds for Research on Public Welfares (201009001 \&2011467003), and the Program for New Century Excellent Talents in University (NCET-10-0532). We acknowledge the support from the local environmental monitoring sites of Nanjing, Suzhou, Pudong, Hangzhou and Ningbo. We also acknowledge the help of L.-W. A. Chen and X. Wang of the Desert Research Institute (Reno, NV, USA), associate professor Haiying Huang of Shanghai Academy of Environmental Sciences on data analysis and C. Freed from US EPA on language correction.

Edited by: A. Stohl 


\section{References}

Andreae, M. O. and Merlet, P.: Emission of trace gases and aerosols from biomass burning, Global Biogeochem. Cy., 15, 955-966, doi:10.1029/2000GB001382, 2001.

Cheng, Y., Engling, G., He, K.-B., Duan, F.-K., Ma, Y.-L., Du, Z.Y., Liu, J.-M., Zheng, M., and Weber, R. J.: Biomass burning contribution to Beijing aerosol, Atmos. Chem. Phys., 13, 77657781, doi:10.5194/acp-13-7765-2013, 2013.

Cheng, Z., Chen, C., Huang, C., Huang, H., Li, L., and Wang, H.: Trans-boundary primary air pollution between cities in the Yangtze River Delta, Acta Scientiae Circumstantiae, 31, 686694, 2011.

Chow, J. C., Engelbrecht, J. P., Watson, J. G., Wilson, W. E., Frank, N. H., and Zhu, T.: Designing monitoring networks to represent outdoor human exposure, Chemosphere, 49, 961-978, doi:10.1016/S0045-6535(02)00239-4, 2002.

Chow, J. C., Doraiswamy, P., Watson, J. G., Antony-Chen, L. W., Ho, S. S. H., and Sodeman, D. A.: Advances in integrated and continuous measurements for particle mass and chemical, composition, JAPCA J. Air Waste Ma., 58, 141-163, doi:10.3155/1047-3289.58.2.141, 2008.

Crutzen, P. J. and Andreae, M. O.: Biomass Burning in the Tropics: Impact on Atmospheric Chemistry and Biogeochemical Cycles, Science, 250, 1669-1678, doi:10.1126/science.250.4988.1669, 1990.

Davies, D. K., Ilavajhala, S., Wong, M. M., and Justice, C. O.: Fire information for resource management system: archiving and distributing MODIS active fire data, IEEE T. Geosci. Remote, 47, 72-79, 2009.

Draxler, R. R. and Rolph, G. D.: HYSPLIT (HYbrid Single-Particle Lagrangian Integrated Trajectory) Model access via NOAA ARL READY, http://ready.arl.noaa.gov/HYSPLIT.php (last access: 1 May 2014), NOAA Air Resources Laboratory, Silver Spring, MD, 2013.

Duan, F. K., Liu, X. D., Yu, T., and Cachier, H.: Identification and estimate of biomass burning contribution to the urban aerosol organic carbon concentrations in Beijing, Atmos. Environ., 38, 1275-1282, doi:10.1016/j.atmosenv.2003.11.037, 2004.

Elias, T., Haeffelin, M., Drobinski, P., Gomes, L., Rangognio, J., Bergot, T., Chazette, P., Raut, J. C., and Colomb, M.: Particulate contribution to extinction of visible radiation: Pollution, haze, and fog, Atmos. Res., 92, 443-454, 2009.

Fu, J. S., Hsu, N. C., Gao, Y., Huang, K., Li, C., Lin, N.-H., and Tsay, S.-C.: Evaluating the influences of biomass burning during 2006 BASE-ASIA: a regional chemical transport modeling, Atmos. Chem. Phys., 12, 3837-3855, doi:10.5194/acp-12-38372012, 2012.

Fu, Q., Zhuang, G., Wang, J., Xu, C., Huang, K., Li, J., Hou, B., Lu, T., and Streets, D. G.: Mechanism of formation of the heaviest pollution episode ever recorded in the Yangtze River Delta, China, Atmos. Environ., 42, 2023-2036, doi:10.1016/j.atmosenv.2007.12.002, 2008.

Fu, X., Wang, S., Zhao, B., Xing, J., Cheng, Z., Liu, H., and Hao, J.: Emission inventory of primary pollutants and chemical speciation in 2010 for the Yangtze River Delta region, China, Atmos. Environ., 70, 39-50, doi:10.1016/j.atmosenv.2012.12.034, 2013.

Fu, X., Wang, S. X., Cheng, Z., Xing, J., Zhao, B., Wang, J. D., and Hao, J. M.: Source, transport and impacts of a heavy dust event in the Yangtze River Delta, China, in 2011, Atmos. Chem. Phys., 14, 1239-1254, doi:10.5194/acp-14-1239-2014, 2014.

Gao, C., Wang, T., Wu, J., Fei, Q., and Cao, L.: Study on a continuous haze weather event during autumn of 2009 in Nanjing, Scientia Meteorologlca Sinica, 32, 246-252, 2012.

Gelencsér, A., May, B., Simpson, D., Sánchez-Ochoa, A., KasperGiebl, A., Puxbaum, H., Caseiro, A., Pio, C., and Legrand, M.: Source apportionment of $\mathrm{PM}_{2.5}$ organic aerosol over Europe: Primary/secondary, natural/anthropogenic, and fossil/biogenic origin, J. Geophys. Res.-Atmos., 112, D23S04, doi:10.1029/2006JD008094, 2007.

Guenther, A., Karl, T., Harley, P., Wiedinmyer, C., Palmer, P. I., and Geron, C.: Estimates of global terrestrial isoprene emissions using MEGAN (Model of Emissions of Gases and Aerosols from Nature), Atmos. Chem. Phys., 6, 3181-3210, doi:10.5194/acp-63181-2006, 2006.

Hand, J. L.: Spatial and Seasonal Patterns and Temporal Variability of Haze and its Constituents in the United States, Cooperative Institute for Research in the Atmosphere (CIRA), Colorado State University, 2011.

Hays, M. D., Fine, P. M., Geron, C. D., Kleeman, M. J., and Gullett, B. K.: Open burning of agricultural biomass: Physical and chemical properties of particle-phase emissions, Atmos. Environ., 39, 6747-6764, doi:10.1016/j.atmosenv.2005.07.072, 2005.

Huang, C., Chen, C. H., Li, L., Cheng, Z., Wang, H. L., Huang, H. Y., Streets, D. G., Wang, Y. J., Zhang, G. F., and Chen, Y. R.: Emission inventory of anthropogenic air pollutants and VOC species in the Yangtze River Delta region, China, Atmos. Chem. Phys., 11, 4105-4120, doi:10.5194/acp-11-4105-2011, 2011.

Huang, K., Zhuang, G., Lin, Y., Fu, J. S., Wang, Q., Liu, T., Zhang, R., Jiang, Y., Deng, C., Fu, Q., Hsu, N. C., and Cao, B.: Typical types and formation mechanisms of haze in an Eastern Asia megacity, Shanghai, Atmos. Chem. Phys., 12, 105-124, doi:10.5194/acp-12-105-2012, 2012.

Huang, X.-F., He, L.-Y., Xue, L., Sun, T.-L., Zeng, L.-W., Gong, Z.-H., Hu, M., and Zhu, T.: Highly time-resolved chemical characterization of atmospheric fine particles during 2010 Shanghai World Expo, Atmos. Chem. Phys., 12, 4897-4907, doi:10.5194/acp-12-4897-2012, 2012.

Knipping, E. M., Kumar, N., Pun, B. K., Seigneur, C., Wu, S.-Y., and Schichtel, B. A.: Modeling regional haze during the BRAVO study using CMAQ-MADRID: 2. Source region attribution of particulate sulfate compounds, J. Geophys. Res.-Atmos., 111, D06303, doi:10.1029/2004JD005609, 2006.

Li, X., Wang, S., Duan, L., Hao, J., Li, C., Chen, Y., and Yang, L.: Particulate and Trace Gas Emissions from Open Burning of Wheat Straw and Corn Stover in China, Environ. Sci. Technol., 41, 6052-6058, doi:10.1021/es0705137, 2007.

Li, W. J., Shao, L. Y., and Buseck, P. R.: Haze types in Beijing and the influence of agricultural biomass burning, Atmos. Chem. Phys., 10, 8119-8130, doi:10.5194/acp-10-8119-2010, 2010.

Lowenthal, D. and Kumar, N.: $\mathrm{PM}_{2.5}$ mass and light extinction reconstruction in IMPROVE, JAPCA J. Air Waste Ma., 53, 11091120, doi:10.1080/10473289.2003.10466264, 2003.

Ministry of Environmental Protection of the People's Republic of China (MEP), and General Administration of Quality Supervision, Inspection and Quarantine of the People's Republic of China (AQSIQ), National Ambient Air Quality Standard (GB, 
3095-2012), China Environmental Science Press, Beijing, China, 2012.

Penner, J. E., Dickinson, R. E., and Oneill, C. A.: Effects of aerosol from biomss burning on the global radiation budget, Science, 256, 1432-1434, doi:10.1126/science.256.5062.1432, 1992.

Reisen, F., Meyer, C. P., and Keywood, M. D.: Impact of biomass burning sources on seasonal aerosol air quality, Atmos. Environ., 67, 437-447, doi:10.1016/j.atmosenv.2012.11.004, 2013.

Rolph, G. D.: Real-time Environmental Applications and Display System (READY), http://ready.arl.noaa.gov (last access: 1 May 2014), NOAA Air Resources Laboratory, Silver Spring, MD, 2013.

Sheesley, R. J., Schauer, J. J., Chowdhury, Z., Cass, G. R., and Simoneit, B. R. T.: Characterization of organic aerosols emitted from the combustion of biomass indigenous to South Asia, J. Geophys. Res.-Atmos., 108, 4285, doi:10.1029/2002jd002981, 2003.

Simon, H. and Bhave, P. V.: Simulating the Degree of Oxidation in Atmospheric Organic Particles, Environ. Sci. Technol., 46, 331339, doi:10.1021/es202361w, 2012.

Song, Y., Tang, X., Xie, S., Zhang, Y., Wei, Y., Zhang, M., Zeng, L., and Lu, S.: Source apportionment of $\mathrm{PM}_{2.5}$ in Beijing in 2004, J. Hazard. Mater., 146, 124-130, doi:10.1016/j.jhazmat.2006.11.058, 2007.

SPECIATE4.3: Agricultural Burning - Composite: http: //cfpub.epa.gov/si/speciate/ehpa_speciate_browse_details. cfm?ptype=P\&pnumber=91103 (last access: 1 May 2014), SPECIATE 4.3, USA, 2009.

Streets, D., Yarber, K., Woo, J. H., and Carmichael, G.: Biomass burning in Asia: Annual and seasonal estimates and atmospheric emissions, Global Biogeochem. Cy., 17, 1099, doi:10.1029/2003GB002040, 2003.

Su, J.-F., Zhu, B., Zhou, T., and Ren, Y.-B.: Contrast Analysis of Two Serious Air Pollution Events Affecting Nanjing and Its Surrounding Regions Resulting From Burning of Crop Residues, Journal of Ecology and Rural Environment, 28, 37-41, 2012.

Sullivan, A. P., Holden, A. S., Patterson, L. A., McMeeking, G. R., Kreidenweis, S. M., Malm, W. C., Hao, W. M., Wold, C. E., and Collett, J. L.: A method for smoke marker measurements and its potential application for determining the contribution of biomass burning from wildfires and prescribed fires to ambient $\mathrm{PM}_{2.5}$ organic carbon, J. Geophys. Res.-Atmos., 113, D22302, doi:10.1029/2008jd010216, 2008.

Tian, D., Hu, Y., Wang, Y., Boylan, J. W., Zheng, M., and Russell, A. G.: Assessment of Biomass Burning Emissions and Their Impacts on Urban and Regional $\mathrm{PM}_{2.5}$ : A Georgia Case Study, Environ. Sci. Technol., 43, 299-305, doi:10.1021/es801827s, 2009.

Wang, Q., Shao, M., Liu, Y., William, K., Paul, G., Li, X., Liu, Y., and Lu, S.: Impact of biomass burning on urban air quality estimated by organic tracers: Guangzhou and Beijing as cases, Atmos. Environ., 41, 8380-8390, doi:10.1016/j.atmosenv.2007.06.048, 2007.

Wang, Q., Shao, M., Zhang, Y., Wei, Y., Hu, M., and Guo, S.: Source apportionment of fine organic aerosols in Beijing, Atmos. Chem. Phys., 9, 8573-8585, doi:10.5194/acp-9-8573-2009, 2009.

Wang, S., Zhao, M., Xing, J., Wu, Y., Zhou, Y., Lei, Y., He, K., Fu, L., and Hao, J.: Quantifying the Air Pollutants Emission Reduction during the 2008 Olympic Games in Beijing, Environ. Sci. Technol., 44, 2490-2496, doi:10.1021/es9028167, 2010.
Wang, S., Xing, J., Chatani, S., Hao, J., Klimont, Z., Cofala, J., and Amann, M.: Verification of anthropogenic emissions of China by satellite and ground observations, Atmos. Environ., 45, 63476358, doi:10.1016/j.atmosenv.2011.08.054, 2011a.

Wang, Y., Hopke, P. K., Rattigan, O. V., Xia, X., Chalupa, D. C., and Utell, M. J.: Characterization of residential wood combustion particles using the two-wavelength aethalometer, Environ. Sci. Technol., 45, 7387-7393, doi:10.1021/es2013984, 2011b.

Watson, J. G.: Visibility: Science and regulation, JAPCA J. Air Waste Ma., 52, 628-713, 2002.

Watson, J. G., Antony Chen, L.-W., Chow, J. C., Doraiswamy, P., and Lowenthal, D. H.: Source apportionment: findings from the US Supersites Program, JAPCA J. Air Waste Ma., 58, 265-288, 2008.

Whitten, G. Z., Heo, G., Kimura, Y., McDonald-Buller, E., Allen, D. T., Carter, W. P. L., and Yarwood, G.: A new condensed toluene mechanism for Carbon Bond CB05-TU, Atmos. Environ., 44, 5346-5355, doi:10.1016/j.atmosenv.2009.12.029, 2010.

Winkler, P.: The growth of atmospheric aerosol particles with relative humidity, Phys. Scripta, 37, 223-230, doi:10.1088/00318949/37/2/008, 1988.

Yan, X., Ohara, T., and Akimoto, H.: Bottom-up estimate of biomass burning in mainland China, Atmos. Environ., 40, 52625273, doi:10.1016/j.atmosenv.2006.04.040, 2006.

Yang, F., Tan, J., Zhao, Q., Du, Z., He, K., Ma, Y., Duan, F., Chen, G., and Zhao, Q.: Characteristics of $\mathrm{PM}_{2.5}$ speciation in representative megacities and across China, Atmos. Chem. Phys., 11, 5207-5219, doi:10.5194/acp-11-5207-2011, 2011.

Yin, C., Zhu, B., Cao, Y., Su, J., Wang, X., and Wang, H.: The origin of crop residue burning impact on air quality of Nanjing, China Environ. Sci., 31, 207-213, 2011.

Zhang, X., Hecobian, A., Zheng, M., Frank, N. H., and Weber, R. J.: Biomass burning impact on $\mathrm{PM}_{2.5}$ over the southeastern US during 2007: integrating chemically speciated FRM filter measurements, MODIS fire counts and PMF analysis, Atmos. Chem. Phys., 10, 6839-6853, doi:10.5194/acp-10-6839-2010, 2010.

Zhang, Z., Engling, G., Lin, C.-Y., Chou, C. C. K., Lung, S.-C. C., Chang, S.-Y., Fan, S., Chan, C.-Y., and Zhang, Y.-H.: Chemical speciation, transport and contribution of biomass burning smoke to ambient aerosol in Guangzhou, a mega city of China, Atmos. Environ., 44, 3187-3195, doi:10.1016/j.atmosenv.2010.05.024, 2010.

Zhang, Y., Duan, Y., Gao, S., and Wei, H.: Characteristics of fine particulate matter during a typical air pollution episode in Shanghai urban area, China Environ. Sci., 31, 1115-1121, 2011.

Zhu, B., Su, J., Han, Z., Yin, C., and Wang, T.: Analysis of a serious air pollution event resulting from crop residue burning over Nanjing and surrounding regions, China Environ. Sci., 30, 585-592, 2010.

Zhu, J., Wang, T., Xing, L., Mu, Q., and Zhou, D.: Analysis on the characteristics and mechanism of a heavy haze episode in Jiangsu Province, China Environ. Sci., 31, 1943-1950, 2011.

Zhu, J., Wang, T., Deng, J., Jiang, A., and Liu, D.: An emission inventory of air pollutants from crop residue burning in Yangtze River Delta Region and its application in simulation of a heavy haze weather process, Acta Scientiae Circumstantiae, 32, 3045$3055,2012$. 